\title{
Agronomic Viability of Mentha piperita Under Quantities and Forms of Application of the Organic Fertilization in the Semiarid of Brazil
}

\author{
Jordany Ramalho Silveira Farias ${ }^{1}$, Paulo César Ferreira Linhares ${ }^{2}$, Janilson Pinheiro de Assis ${ }^{2}$, \\ Roberto Pequeno de Sousa ${ }^{2}$, Maria Francisca Soares Pereira ${ }^{2}$, Eudes de Almeida Cardoso ${ }^{2}$, \\ José Aluísio de Araújo Paula ${ }^{3}$, Neurivan Vicente da Silva ${ }^{1}$, Francisco Laíres Cavalcante ${ }^{1}$, \\ Ariana da Mota Oliveira ${ }^{1} \&$ Lunara de Sousa Alves ${ }^{2}$ \\ ${ }^{1}$ Federal University of Campina Grande, Campina Grande, Paraíba, Brazil \\ ${ }^{2}$ Jitirana Research Group, Department of Agronomic and Forestry Sciences, Federal Rural Semi-Arid University, \\ Mossoró, RN, Brazil \\ ${ }^{3}$ Brazilian Service to Support at Micro and Small Enterprises of Rio Grande do Norte, Mossoró, RN, Brazil \\ Correspondence: Jordany Ramalho Silveira Farias, Federal University of Campina Grande, Campina Grande, \\ Paraíba, Brazil. E-mail: jordanypb7@hotmail.com
}

Received: June 1, 2019

Accepted: July 13, 2019 Online Published: September 30, 2019

doi:10.5539/jas.v11n16p54

URL: https://doi.org/10.5539/jas.v11n16p54

\begin{abstract}
The use of available resources in the property is of paramount importance for the sustainability of the system. In this sense, the objective was to study the agronomic viability of mint Mentha piperita under amounts and forms of application of the organic fertilization in the semiarid of Brazil. The experiment was conducted at the experimental farm Rafael Fernandes in the period from August 2017 to November 2017, in the Alagoinha district, rural area of Mossoró-RN. The experimental design was a randomized complete block design in a $5 \times 2$ factorial scheme, with four replications. The first factor consisted of the quantities of the mixture of jitirana plus bovine manure $\left(0.0,1.4,2.8,4.2\right.$ and $\left.5.6 \mathrm{~kg} \mathrm{~m}^{-2}\right)$, the second factor was composed by the way of handling the mixture of jitirana and bovine manure (incorporated and in cover). For the mint crop, the cultivar Mentha piperita was planted. The following characteristics were evaluated: biomass height, green mass production; number of bunches; dry mass production; oil content and oil production. No interaction was observed between the amounts of organic fertilization in the forms of management of organic fertilization in the characteristics evaluated. The best agronomic performance of mint was observed in the amount of $4.2 \mathrm{~kg} \mathrm{~m}^{-2}$, with green mass production of $1.5 \mathrm{~kg}$ $\mathrm{m}^{-2}$, equivalent to 16.4 units $\mathrm{m}^{-2}$. Organic fertilization becomes viable option to be used in the fertilization of the mint.
\end{abstract}

Keywords: organic fertilization, physical analysis, Merremia aegyptia L., agroecological production

\section{Introduction}

The peppermint, belonging to the genus Mentha of the family Lamiaceae, being an aromatic plant, it is among the most popular herbs for use in the form of teas in order to treat headaches and disorders gastrointestinal and respiratory disorders. The drug, is used mainly to obtain the oil, is widely used as flavoring agent, food additive, oral hygiene products and pharmaceutical preparations (Simões et al., 1998).

Among farmers working in the family production system, the presence of this species in their production areas is very common, considering their use in folk medicine as well as in cooking. Its production occurs in organic system on the farms of family-based farmers who cultivate sustainably for consumption and commercialization (Linhares et al., 2018).

The organic production of vegetables has been efficient in the northeastern region of Brazil. The demand for healthy food, produced in systems ecologically sustainable, becomes increasingly reality in the country, from the point of view of the consumer, contributing more and more to a demand in products resulting from the non-use of chemical products (Martins, 2008).

Among the plant species produced in the northeast region, is found Mentha piperita $\mathrm{L}$. it is an aromatic plant belonging to the Lamiacea family, also known as peppermint and peppermint, its essential oil is considered industrially important (David, Boaro, \& Marques, 2006). 
Due to the need to increase the production of peppermint, the use of resources readily available at the farm, such as cattle manure, goats and poultry, is important, guaranteeing an economic return to the farmer (Linhares et al., 2014).

The use of the mixture of fertilizers of plant and animal origin, contributes greatly to the greater availability of nutrients as a function of the organic carbon in the fertilizer of animal origin, which acts as energy source for the greater availability of microorganism in the soil, being these decomposers of the organic material (Novaes, 2007) In this way, the mixing of organic fertilizers from different sources becomes promising for agricultural cultivation.

Due to the importance of finding practical solutions that can reduce the problems that hinder family farmers in the production of medicinal plants, using resources available on the farm, the objective was to evaluate agronomic viability of mint (Mentha piperita L.) under quantities and forms of application of the organic fertilization in the semiarid of Brazil.

\section{Materials and Methods}

\subsection{Study Area}

The experiment was conducted in the research area of the Rafael Fernandes Experimental Farm of the Federal Rural Semi-Arid University (UFERSA), in the period from August 2017 to November 2017, in soil of the experimental area was classified as Eutrophic Red Yellow Argissolo, caatinga hyperxerophilic phase and flat relief (Embrapa, 2006). The area is located in the Alagoinha district, $20 \mathrm{~km}$ from the Mossoró, Northeastern Brazil. The farm comprises of some 400 hectares (Rêgo et al., 2016).

According to Kottek et al. (2006) and the classification of Köppen, the local climate is BSwh', dry and very hot, the dry season being normally from June to January, and a rainy season being from February to May. The average annual rainfall is $673.9 \mathrm{~mm}$ and the average relative humidity is $68.9 \%$.

Before the installation of the field experiment, soil samples were collected to a $0-20 \mathrm{~cm}$ layer and then sent to be processed and analyzed in the UFERSA Water, Soil and Plant Analysis Laboratory, providing the following results: $\mathrm{pH}\left(\right.$ water 1:2,5) $=6.80$; exchangeable cations $\mathrm{Ca}=0.48 \mathrm{cmol}_{\mathrm{c}} / \mathrm{dm}^{3} ; \mathrm{Mg}=0.70 \mathrm{cmol}_{\mathrm{c}} / \mathrm{dm}^{3} ; \mathrm{K}=40.5$ $\mathrm{mg} / \mathrm{dm}^{3} ; \mathrm{Na}=10.5 \mathrm{mg} / \mathrm{dm}^{3} ; \mathrm{P}($ Mehlich $)=2.8 \mathrm{mg} / \mathrm{dm}^{3} ;$ organic matter $=0.90 \mathrm{~g} / \mathrm{kg} ;$ Coarse $\mathrm{sand}=630 \mathrm{~g} / \mathrm{kg}$; fine sand $=270 \mathrm{~g} / \mathrm{kg}$; silte $=20 \mathrm{~g} / \mathrm{kg}$; clay $=70 \mathrm{~g} / \mathrm{kg}$, soil density $=1.42 \mathrm{~g} / \mathrm{cm}^{3}$.

\subsection{Statistical Delineation and Treatments}

The experimental design of randomized complete blocks with the treatments arranged in $5 \times 2$ factorial scheme, with four replicates. The first factor consisted of different amounts of the jitirana mixture plus bovine manure $\left(0.0,1.4,2.8,4.2\right.$ and $\left.5.6 \mathrm{~kg} / \mathrm{m}^{2}\right)$. The second factor was composed by the management methods of jitirana mixture plus bovine manure (incorporated and cover).

The propagation of the lettuce seedlings was done in expanded polyethylene trays of 128 cells, containing vermiculite substrate. The seedlings were grown in a greenhouse for 15 days with $50 \%$ shading until they reached about $10 \mathrm{~cm}$ in height. Each plot had a total area of $1.96 \mathrm{~m}^{2}(1.40 \mathrm{~m} \times 1.40 \mathrm{~m})$ containing 49 lettuce plants spaced of $0.20 \mathrm{~m} \times 0.20 \mathrm{~m}$. The harvest area of each plot was $1.0 \mathrm{~m}^{2}(1.00 \mathrm{~m} \times 1.00 \mathrm{~m})$ containing 25 lettuce plants.

\subsection{Nutrient Content of Hairy Woodrose}

The hairy woodrose (Merremia aegyptia L.) used as green manure was collected before the start of flowering in various locations of the rural zone of the Mossoró-RN municipality. After collecting, the plants were crushed in a conventional forage machine to obtain fragmented particles approximately 2.0 to $3.0 \mathrm{~cm}$ in size, which were dried in sun to reach a moisture content of $12 \%$; a sample of this material was then subjected to laboratory analyses, which revealed a chemical composition of: $\mathrm{N}=19.8 \mathrm{~g} / \mathrm{kg} ; \mathrm{P}=8.6 \mathrm{~g} / \mathrm{kg} ; \mathrm{K}=22.4 \mathrm{~g} / \mathrm{kg} ; \mathrm{Ca}=9.7 \mathrm{~g} / \mathrm{kg}$; $\mathrm{Mg}=3.0 \mathrm{~g} / \mathrm{kg} ; \mathrm{S}=1.6 \mathrm{~g} / \mathrm{kg}$ and a $\mathrm{C} / \mathrm{N}$ ratio of $23 / 1$. Quantified as a function of dry matter, taking into account the $12 \%$ humidity, being incorporated in the $0-20 \mathrm{~cm}$ soil.

During the period of stay of residues in the soil, prior to planting, irrigations were made in order to maintain soil moisture at $70 \%$ of field capacity, and this is an ideal condition for nitrification (Novais, 2007).

\subsection{Harvesting and Evaluation of the Characteristics Studied}

The harvest was performed 60 days after transplanting (DAT). After harvesting, plants were transported to the Post-Harvest of Vegetables Laboratory of the Agrarian Science Center of the Federal Rural University of the semi-arid. 
The following characteristics were evaluated: biomass height (was measured in the field, in centimeters using millimeter ruler, twenty plants per plot), green mass production (It was obtained through the cut of the aerial part, above $5 \mathrm{~cm}$, within the useful area, weighed in a precision scale of $1.0 \mathrm{~g}$, expressed in $\mathrm{kg} \mathrm{m}^{-2}$ ); number of bunches (determined by the division of production in $\mathrm{kg} \mathrm{m}^{-2}$ per $100 \mathrm{~g}$, corresponding to the weight of the sauce in the supermarket of Mossoró, Northeastern Brazil); dry mass production (was obtained from a forced-air heating oven at $65^{\circ} \mathrm{C}$, to constant mass and expressed in $\mathrm{kg} \mathrm{m}^{-2}$ ), Oil content (It was defined by the ratio between the mass in grams of essential oil by the mass of dry leaves inserted into the distillation flask $\times 1000$, being expressed in $\mathrm{g} \mathrm{kg}^{-1}$ ) and Oil production (It was determined by the oil content in $\mathrm{g} \mathrm{kg}^{-1} \times$ the production of dry mass in $\mathrm{kg} \mathrm{m}^{-2}$, being expressed in $\mathrm{g} \mathrm{m}^{-2}$ ).

For the determination of oil content and yield, dry leaves were used, as recommended by Martins (2000), which states that the water content in the leaves, after drying, allows the vapor stream generated in the extractor to remove the volatile substances stored in cells, when compared to the green material. Second Guenther (1972), due to the high moisture content in the plants, there is tendency of agglutination, preventing the vapor from penetrating evenly in the tissues of the plant. In determining the essential oil content and yield, dry mass samples were subjected to hydrodistillation in a modified Clevenger apparatus for $1.5 \mathrm{~h}$, using $600 \mathrm{~mL}$ of distilled water in $1 \mathrm{~L}$ distillation flask (Simões et al., 2003).

\subsection{Statistics Analysis}

Analyses of variance were conducted for the evaluated characteristics using the ESTAT software (Kronka \& Banzato, 1995). Response curve adjustment for the quantitative factor was performed using the Table Curve software (Jandel scientific, 1991). The response functions were evaluated based on the following criteria: biological rationale, significance of the mean square of the regression (QMRr), high coefficient of determination (R2), significance of the regression parameters, using the $t$ test at $\mathrm{p}<0.01$ probability).

\section{Results and Discussion}

There was no significant interaction between the factors tested in any of the characteristics evaluated (Table 1).

Table 1. F values for biomass height (BH), production of mint (PM), number of bunches (NB), dry mass (DM), oil content $(\mathrm{OC})$ and oil production of mint $(\mathrm{OP})$ as a funtion of organic fertilisation

\begin{tabular}{lllllll}
\hline Causes of variation & GL & BH & NB & DM & OC & OP \\
\hline Amounts (A) & 4 & $4.33^{* *}$ & $12.82^{* *}$ & $14.29^{* *}$ & $13.71^{* *}$ & $16.56^{* *}$ \\
Management of organic fertilisation (M) & 1 & $12.17^{* *}$ & $21.13^{* *}$ & $8.90^{* *}$ & $1.51^{\mathrm{ns}}$ & $11.55^{* *}$ \\
A $\times$ B & 4 & $0.57^{\mathrm{ns}}$ & $1.20^{\mathrm{ns}}$ & $1.66^{\mathrm{ns}}$ & $1.93^{\mathrm{ns}}$ & $0.90^{\mathrm{ns}}$ \\
Treatments & 9 & - & - & - & - & - \\
Bloks & 3 & $8.64^{* *}$ & $7.29^{* *}$ & $10.8^{* *}$ & $8.65^{\mathrm{ns}}$ & $14.50^{* *}$ \\
Waste & 27 & - & - & - & - & - \\
CV $(\%)$ & - & 10.41 & 13.70 & 12.80 & 8.88 & 12.25 \\
\hline
\end{tabular}

Note. $* *=\mathrm{P}<0.01$, statistical significance at $1 \%$ probability $*=\mathrm{P}<0.05$, statistical significance at $5 \%$ probability and $^{\text {ns }}=$ not significant.

There was a point of maximum height of the mint biomass, with a value of $28 \mathrm{~cm}$ in the amount of $4.2 \mathrm{~kg} \mathrm{~m}^{-2}$ (Figure 1). For the application forms of the organic fertilizer, there was statistical superiority when incorporating the organic fertilizer in relation to the fertilizer disposition at the soil surface, with values of 27.6 and $22.4 \mathrm{~cm}$, respectively (Table 2). Linhares et al. (2018) studied agronomic efficiency of organic fertilized in the production of the intercropping of coriander and mint, found biomass height of $29 \mathrm{~cm}$, in the amount of $6.0 \mathrm{~kg} 2.0 \mathrm{~m}^{-2}$, being higher than the data obtained in this study. 


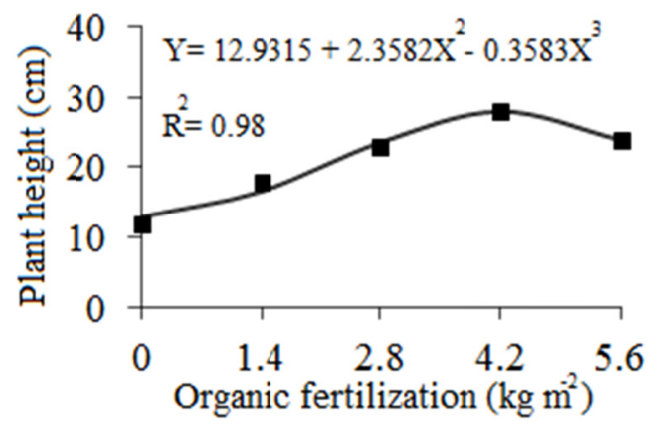

Figure 1. Height of the mint biomass as a function of organic fertilizer

For the green mass production and number of bunches, there was a maximum point, with $1.50 \mathrm{~kg} \mathrm{~m}^{-2}$ of mint, equivalent to 16.4 units $\mathrm{m}^{-2}$ at the amount of $4.2 \mathrm{~kg} \mathrm{~m}^{-2}$ (Figures 2A and 2B). Among the forms of biomass management (incorporated and covered), there was statistical difference with mean values of 1.7 and $1.4 \mathrm{~kg} \mathrm{~m}^{-2}$, for green mass production and 15.8 and 12.4 units $\mathrm{m}^{-2}$, for number bunches, respectively (Table 2). The number of sauces is an important feature, being the marketing form of mint. Guerra et al. (2015) studying the intercropping of lettuce with medicinal plants in Amazonian conditions, found a fresh peppermint mass of 0.55 and $0.33 \mathrm{~kg} \mathrm{~m}^{-2}$, in the single and intercropping cultivation, respectively, being inferior to this research.

Linhares et al. (2018) studied agronomic efficiency of organic fertilized in the production of the intercropping of coriander and mint, green mass production and number of bunches of $3.94 \mathrm{~kg} 2.0 \mathrm{~m}^{-2}$ and 39.4 units $2.0 \mathrm{~m}^{-2}$, equivalent to $1.97 \mathrm{~kg} \mathrm{~m}^{-2}$ and 19.7 units $\mathrm{m}^{-2}$, respectively, being higher than the data obtained in this study.

Vicente; Maia \& Oliveira (2008) studying the production of medicinal plants with filter cake, found a production of $400 \mathrm{~g} \mathrm{~m}^{-2}$ mint biomass, equivalent to $0.4 \mathrm{~kg} \mathrm{~m}^{-2}$ corresponding to 4.0 bundles, being higher than the data obtained in this study. This inferiority is probably due to the fact mint harvest has been carried out at 240 days after planting, causing leaf senescence, with reduced green mass production of the plant.
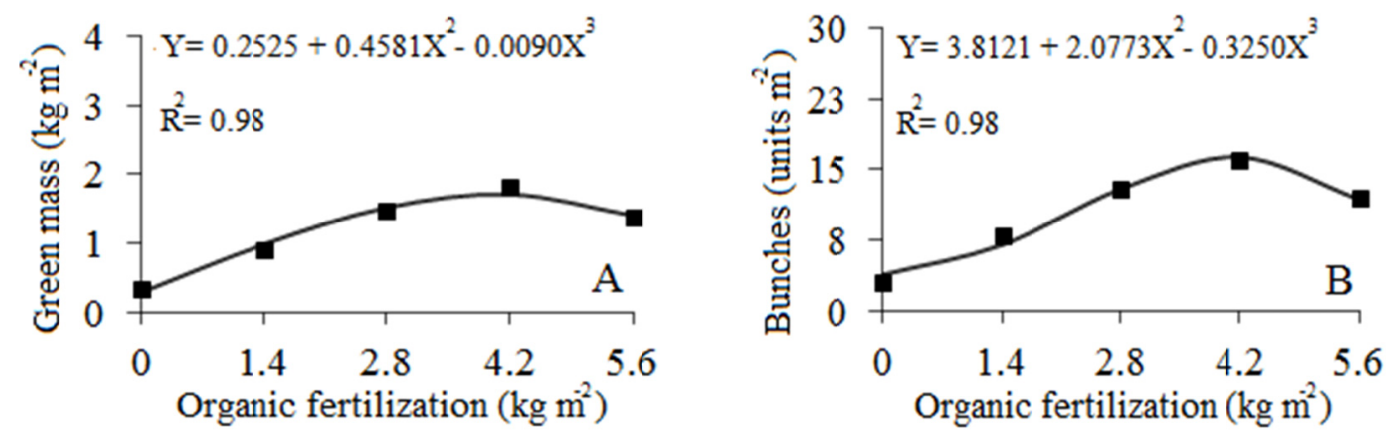

Figure 2. Green mass production (A) and number of bunches (B) of mint as a function of amounts of organic fertilizer

Table 2. Biomass height, express in $\mathrm{cm}(\mathrm{BH})$ and green mass, express in $\mathrm{kg} \mathrm{m}^{-2}$ (GM) and number of bunches, express units $\mathrm{m}^{-2}(\mathrm{NB})$ under types of organic fertilizers

\begin{tabular}{llll}
\hline Organics fertilizers & BH & GM & NB \\
\hline incorporated & $27.6 \mathrm{a}$ & $1.7 \mathrm{a}$ & $15.8 \mathrm{a}$ \\
Cover & $22.4 \mathrm{~b}$ & $1.4 \mathrm{~b}$ & $12.4 \mathrm{~b}$ \\
$\mathrm{CV}(\%)$ & 16.2 & 13.2 & 13.5 \\
\hline
\end{tabular}

Note. * Means followed by the same letter in the column do not differ by $\mathrm{F}$ test at the $5 \%$ probability level.

A similar value to yield was observed for dry mint mass, with a maximum value of $232 \mathrm{~g} \mathrm{~m}^{-2}$, in the amount of 4.2 $\mathrm{kg} \mathrm{m}^{-2}$ of organic fertilizer (Figure 3). Regarding the forms of application of the jitirana biomass (incorporated and covered), they differed statistically, with average values of 200 and $180 \mathrm{~g} \mathrm{~m}^{-2}$ of dry mass, respectively (Table 5). 
Lower behavior was observed by Vicente, Maia, and Oliveira (2008) studying the production of medicinal plants with filter cake found dry biomass of mint of $100 \mathrm{~g} \mathrm{~m}^{-2}$.

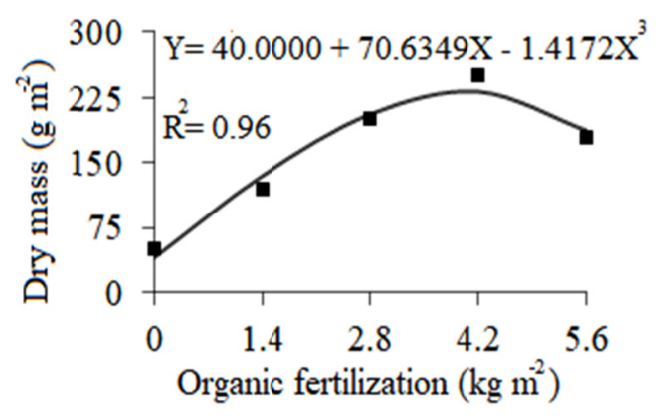

Figure 3. Dry mass of mint as a function of amounts of organic fertilizer

In the percentage of oil, there was a point of maximum production, with maximum value of $6.73 \mathrm{~g} \mathrm{~kg}^{-1}$, in the amount of $4.2 \mathrm{~kg} \mathrm{~m}^{-2}$ of organic fertilization (Figure 4). There was an average increase of $6.0 \mathrm{~g} \mathrm{~kg}^{-1}$ of essential oil between the amount of $\left(4.2 \mathrm{~kg} \mathrm{~m}^{-2}\right)$ and the smaller amount of organic fertilization $\left(0.0 \mathrm{~kg} \mathrm{~m}^{-2}\right)$. Santos; Brezan \& Serra (2013) studying the biomass production, content and composition of the essential oil of Mentha spicata, under organic production, found oil content of $0.96 \%$, equivalent to $9.6 \mathrm{~g} \mathrm{~kg}^{-1}$, being higher to this research. Linhares et al. (2018) studied agronomic efficiency of organic fertilized in the production of the intercropping of coriander and mint, found oil content of $2.1 \mathrm{~g} \mathrm{~kg}^{-1}$, being small to this research. The inferiority is possibly due to the smaller amount of fertilizer used compared to the present work.

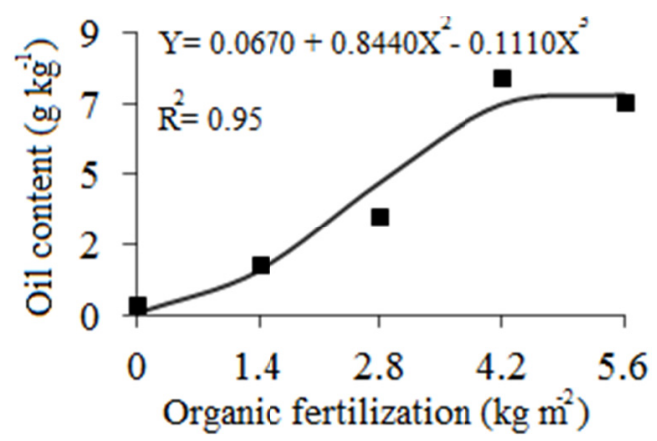

Figure 4. Oil content of mint as a function of amounts of organic fertilizer

There was a maximum yield of mint oil in the amount of $4.2 \mathrm{~kg} \mathrm{~m}^{-2}$ organic fertilization, with a maximum value of $1.37 \mathrm{~g} \mathrm{~m}^{-2}$ (Figure 5). However, for the management of the biomass of jitirana plus bovine manure, there was no statistical difference, with mean values of 1.4 and $1.3 \mathrm{~g} \mathrm{~m}^{-2}$, respectively (Table 3). The higher yield is probably due to the greater availability of nutrients in the soil at the moment of greater nutritional requirement of the mint, thus contributing to an expressive yield of oil. Therefore, superior behavior was observed by Amorim (2014), under different organic substrates in the growth, yield and chemical composition of the essential oil of medicinal species, observing the average oil content in mint of $4.0 \mathrm{~g} \mathrm{~kg}^{-1}$. 


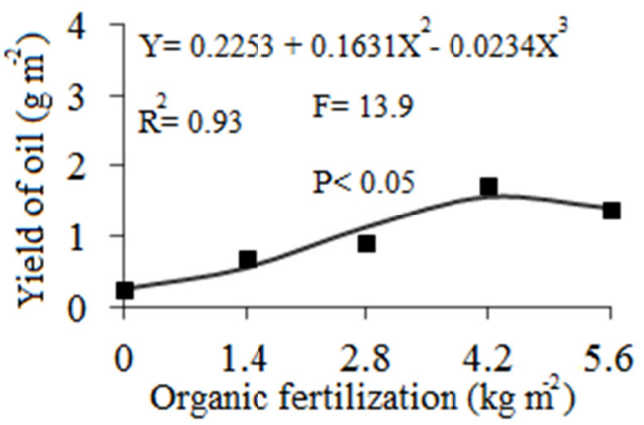

Figure 5. Yield of oil content of mint as a function of amounts of organic fertilizer

Table 3. Dry mass, express in $\mathrm{g} \mathrm{m}^{-2}(\mathrm{DM})$, oil content, express $\mathrm{g} \mathrm{kg}^{-1}(\mathrm{OC})$ and yield oil, express $\mathrm{g} \mathrm{m}^{-2}(\mathrm{YO})$ under types of organic fertilizers

\begin{tabular}{llll}
\hline Organics fertilizers & DM & OC & YO \\
\hline incorporated & $200 \mathrm{a}$ & $6.8 \mathrm{a}$ & $1.4 \mathrm{a}$ \\
Cover & $180 \mathrm{~b}$ & $6.4 \mathrm{~b}$ & $1.3 \mathrm{a}$ \\
$\mathrm{CV}(\%)$ & 12.7 & 14.2 & 14.5
\end{tabular}

Note. * Means followed by the same letter in the column do not differ by $\mathrm{F}$ test at the $5 \%$ probability level.

\section{Conclusions}

The best agronomic performance of mint was observed in the amount of $4.2 \mathrm{~kg} \mathrm{~m}^{-2}$, with green mass production of $1.5 \mathrm{~kg} \mathrm{~m}^{-2}$, equivalent to 16.4 units $\mathrm{m}^{-2}$.

Organic fertilization becomes viable option to be used in the fertilization of the mint.

\section{References}

Amorim, E. L. (2014). Avaliação de diferentes substratos orgânicos no crescimento, rendimento e na composição química do óleo essencial de espécies medicinais (Dissertação de mestrado, Universidade Federal do Recôncavo da Bahia, Centro de Ciências Agrárias, Ambientais e Biológicas).

David, E. F. S., Boaro, C. S. F., \& Marques, M. O. M. (2006). Rendimento e composição do óleo essencial de Mentha piperita L., cultivada em solução nutritiva com diferentes níveis de fósforo. Revista Brasileira de Plantas Medicinais, 8, 183-188.

EMBRAPA (Empresa Brasileira de Pesquisa Agropecuária). (2006). Sistema brasileiro de classificação de solos (2nd ed., p. 306). Rio de Janeiro: Embrapa.

Guerra, A. M. N., Ferreira, J. B. A., Lima, T. C., Costa, A. C. M., \& Tavares, P. R. F. (2015). Cultivo consorciado de alface com plantas medicinais nas condições amazônicas. Revista Agrarian, 8, 369-375.

Kottek, M., Grieser, J., Rudolf, B., \& Rubel, F. (2006). Mapa mundial da classificação climática de Köppen-Geiger atualizada. Meteorologische Zeitschrift, 15, 259-263. https://doi.org/10.1127/0941-2948/ 2006/0130

Jandel Scientific. (1991). Table Curve: Curve Fitting Software (p. 280).

Kronka, S. N., \& Banzato, D. A. (1995). (Estat) system for statistical analysis (p. 243). Jaboticabal: Funep.

Guenther, E. (1972). The essential oils (6th ed., p. 63). Huntington, N.Y.: R.E. Krieger.

Linhares, P. C. F., Assis, J. P., Sousa, R. P., Sá, J. R., Pereira, M. F. S., Ramalho, W. B., ... Pereira K. L. V. (2018). Optimized amount of hairy woodrose (Merremia aegyptia L.) in the productivity of coriander cultivars. Bulgarian Journal of Agricultural Science, 24, 654-659.

Linhares, P. C. F., Maracajá, P. B., Pereira, M. F. S., Assis, J. P., \& Sousa, R. P. (2014). Roostertree (Calotropis procera) under different amounts and periods of incorporation on yield of coriander. Revista Verde de Agroecologia e Desenvolvimento Sustentável, 9, 07-12.

Martins, P. M. (2000). Influência da temperatura e velocidade do ar de secagem no teor e na composição quimica do óleo essencial de capim limão (Cymbopogum citratus (D.C.) STAPF) (Dissertação Mestrado, Área de 
Concentração em Plantas Medicinais, Departamento de Engenharia Agrícola, Plantas Medicinais, Universidade Federal de Viçosa).

Novais, R. F. (2007). Fertilidade do solo. In E. J. Muerer (Ed.), Fatores que influenciam o crescimento e o desenvolvimento das plantas (pp. 65-90). Viçosa: SBCS.

Rêgo, L. G. S., Martins, C. M., Silva, E. F., Silva, J. J. A., \& Lima, R. N. S. (2016). Pedogenesis and classification of soils of an experimental farm in Mossoró, Rio Grande do Norte, Brazil. Revista Caatinga, 29, 1036-1042. https://doi.org/10.1590/1983-21252016v29n430rc

Santos, G. A., Brenzan, M. A., \& Serra, L. Z. (2013). Influência do cultivo na produção de biomassa, teor e composição do óleo essencial de Mentha spicata. SaBios: Revista Saúde e Biologia, 8, 19-25.

Simões, C. M. O. (2003). Farmacognosia: Da planta ao medicamento (5th ed., p. 1102). Porto Alegre/Florianópolis: Editora UFRGS/Editora UFSC.

Simões, C. M. O., Mentz, L. A., Schenkel, E. P., Irgang, B, E., \& Stehmann, J. R. (1998). Plantas da medicina popular no Rio Grande do Sul (5th ed., p. 173). Porto Alegre: Editora da Universidade-UFRGS.

Vicente, E. C., Maia, E., \& D’oliveira, P. S. (2008). Produção de plantas medicinais adubadas com torta de filtro. Iniciação Científica Cesumar, 10, 07-12.

\section{Copyrights}

Copyright for this article is retained by the author(s), with first publication rights granted to the journal.

This is an open-access article distributed under the terms and conditions of the Creative Commons Attribution license (http://creativecommons.org/licenses/by/4.0/). 